\title{
NUTRITIONAL VALUE AND FATTY ACID COMPOSITIONS OF CHLORELLA VULGARIS GROWN UNDER AUTOTROPHIC AND HETEROTROPHIC CONDITIONS
}

\author{
Mostafa El-Sheekh ${ }^{1}$ and Alaa A. Fathy ${ }^{2^{*}}$ \\ ${ }^{1}$ Botany Department, Faculty of Science, Tanta University, Tanta, Egypt. \\ ${ }^{2 *}$ (corresponding author) Botany Department, Faculty of Science, Alexandria \\ University, Alexandria, Egypt.
}

\begin{abstract}
Chlorophyll -a content of autotrophic cells of Chlorella vulgaris was double that estimated in heterotrophic cells, while chlorophyll -b content of autotrophic cells was nearly half the value recorded for heterotrophic cells. Carotenoids content of heterotrophic cultures decreased by $30.82 \%$ compared to that value of autotrophic cells. There was a slight decrease in the protein content of $C$. vulgaris under heterotrophic conditions. When the composition of total free amino acids and proline of $C$. vulgaris grown under autotrophic conditions is compared to that grown heterotrophically, it was observed that a significant increase in total free amino acids and proline in heterotrophic cultures. The percentage of most fatty acids of heterotrophic cells was relatively higher than autotrophic ones. There was no qualitative difference between autotrophic and heterotrophic cultures, except for the fatty acid 16:02 which was absent under autotrophic conditions.
\end{abstract}

Keywords: Fatty acids, Chlorella vulgaris, autotrophic, heterotrophic.

\section{Introduction}

Natural products play an important role in the drug production (Cragg et al., 1997). Thus, the investigation of new algal chemical compounds, as natural source of natural products, has proved to be a promising area of pharmaceutical study (Blunt et al., 2005; Singh et al., 2005; Cardozo et al., 2007).

Carotenoids are natural pigments exercising important biological functions in algae, plants and animals (Polivka and Sundström, 2004; Cardozo et al., 2007). For human nutritional purposes, some carotenoids offer provitamin A activity (Mayne, 1996). They are directly providing photoprotection against UV light photooxidation in the skin beside their key role factor in reducing the incidence of many diseases (Cantrell et al., 2003; Astley et al., 2004; Sies and Stahl, 2004; Aust et al., 2005). 
Polyunsaturated fatty acids (PUFAs), especially the essential omega-6 and omega-3 fatty acids, play key roles in nearly all cellular metabolic process in human body because there is no synthetic mechanism for their production inside the body (Funk, 2001; Sayanova and Napier, 2004). Thus an external source is needed to provide the human body with its need of such essential fatty acids. Most of fatty acids production processes investigated to date have been based on photoautotrophic growth (Sánchez et al., 2002; Molina et al., 2003).

It is well known that algae are at the bottom of the aquatic food chain. The primary determinant in establishing the food quality transferred through successive levels of the food web appears to be the biochemical composition of the algae (fatty acids, amino acids, protein and other pharmaceutical products) (Droop, 1974; Brown and Miller, 1992; Morimoto et. al., 1995; Shibata et. al., 2003; Cardozo et al., 2007).

Algae are considered as the main natural source for both carotenoids and essential fatty acids beside other valuable nutritional value. The green alga Chlorella has attracted considerable interest for commercial production of functional food such as polyunsaturated fatty acids by $C$. sorokiniana (Chen and John, 1991) and leutin by C. protothecoides (Shi et. al., 2002). Chlorella zofingiensis has been proposed as a promising producer of the high-value carotenoids (Orosa et. al., 2000; Ip and Chen, 2005). The correlations between cultivation conditions and percentage of carotenoids, protein and fatty acids contents were subjects of many studies (Piorreck et. al., 1984; Vladimirova et. al., 2000; Petkov and Garcia, 2007).

Fatty acids yield and productivity in photoautotrophic systems are low, because the insufficiency of light caused by mutual shading of cells (Barclay et al., 1994; Chen et al., 1996). For enhancement of fatty acid production by microalgae, the development of a heterotrophic growth is desirable (Wen, 2001). The concept that autotrophic microorganisms can utilize only inorganic carbon dioxide as a carbon source has been modified over years (Shugarman and Appleman, 1966; Bennett and Hobbie, 1972; Cho et al., 1981; Feng et al., 2005).

In this study an attempt was made to evaluate the nutritional value of Chlorella vulgaris grown under autotrophic and heterotrophic conditions concerning their content of carotenoids, protein, proline, total free amino acids and fatty acids. It was an attempt too, to answer the question: Does heterotrophy enhance fatty acids production? Also, validity of fatty acids composition as stable taxonomic feature for the genus Chlorella was briefly discussed as aside issue. 


\section{Materials and Methods}

\section{Culture conditions:}

The modified basal medium (Chen et al., 1996) (described in Wu and Shi, 2007) containing $\left(\mathrm{mg} \mathrm{L}^{-1}\right) \mathrm{KH}_{2} \mathrm{PO}_{4} 1250, \mathrm{MgSO}_{4} 1000$, EDTA 500, $\mathrm{H}_{3} \mathrm{BO}_{3} 114.2$, $\mathrm{CaCl}_{2}$ 111, $\mathrm{FeSO}_{4}$ 49.8, $\mathrm{ZnSO}_{4}$ 88.2, $\mathrm{MnCl}_{2}$ 14.2, $\mathrm{MoO}_{3}$ 7.1, $\mathrm{CuSO}_{4} 15.7$ and $\mathrm{Co}\left(\mathrm{NO}_{3}\right)_{2} 4.9$ and supplemented with $10 \mathrm{~g} \mathrm{~L}^{-1}$ glucose (as the carbon source) was used for heterotrophic cultivations of Chlorella vulgaris. Cultivation of axenic $C$. vulgaris was carried out in 250-ml flasks (each containing $100 \mathrm{ml}$ of medium). All media in the flasks were sterilized in autoclave at $121^{\circ} \mathrm{C}$ for $20 \mathrm{~min}$. The cultures were incubated at $30^{\circ} \mathrm{C}$ with orbital shaking at $130 \mathrm{rpm}$ under darkness. Autotrophic cultures were continuously illuminated with $40 \mathrm{~W}$ fluorescent lamps (3500 lux). Experiment for each trial was carried out in triplicates. Each culture was tested occasionally for contamination by bacteria or fungi by incubating an aliquot with peptonic agar at $30{ }^{\circ} \mathrm{C}$ for at least 2 days in the dark. Cultures used for chemical analysis were harvested after nine days during the exponential phase.

\section{Estimation of pigments:}

Algal cells were homogenized at $1000 \mathrm{rpm}$ for one min, using $100 \%$ acetone (50 $\mathrm{ml}$ for each $\mathrm{g}$ sample). The homogenate was filtered through two layer cheese cloths, and was centrifuged at $2500 \mathrm{rpm}$ for ten min. The supernatant was separated and the absorbance was read at 662, 645 and $470 \mathrm{~nm}$ for chl-a, chl-b and carotenoids, according to the method described by Dere et al., (1998). The amount of these pigments was calculated according to the formulas of Lichtenthaler and Wellburn (1985):

Chl-a $=11.75$ A662 -2.350 A645

Chl-b $=18.61$ A645 - 3.960 A662

Carot. $=1000$ A470 - 2.270 Chl-a -81.4 Chl-b / 227

\section{Estimation of total free amino acids:}

Total free amino acids were estimated according to the method of Yem and Cocking (1955). One $\mathrm{ml}$ aliquot of the acidified extract was mixed with $2 \mathrm{ml}$ sodium acetate buffer ( $\mathrm{pH}$ 6.5) and $1 \mathrm{ml}$ freshly prepared ninhydrin reagent. The resulting colour was then read at $570 \mathrm{~nm}$ with Perkin Elmer spectrophotometer. Leucine was used as a standared.

\section{Estimation of free proline:}

Free proline estimation was carried out using the acid ninhydrin method of Bates et al., (1973). The absorbance was read at $520 \mathrm{~nm}$ using Perkin Elmer spectrophotometer, and the proline concentration was calculated from a proline standard curve. 


\section{Estimation of protein:}

The protein was estimated according to Folin-Ciocalteu method described by Hartree (1972), and the resulting color was measured at $650 \mathrm{~nm}$ using Perkin Elmer spectrophotometer, related to a standard curve of bovine serum albumin.

Determinations of lipids and fatty acid composition:

Fatty acids were analyzed by Gas Liquied Chromatography (GLC) (Schimadzu GC4-CM). The relative peak areas on the chromatogram were estimated after tracing them on sectional paper and thus the content (\%) of different fatty acids was estimated. The conditions for GLC analysis were: Column size: $3 \mathrm{~mm} \times 3 \mathrm{~mm}$ id; carrier gas: nitrogen; fuel: hydrogen-air mixture; hydrogen flow rate: $1 \mathrm{ml} \mathrm{min}$

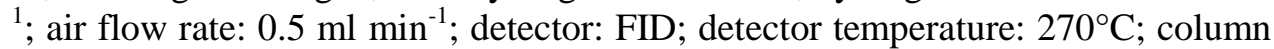
temperature: $180^{\circ} \mathrm{C}$. Extraction and methanolysis were performed according to the method described by Chalvardjian (1964) and Moneam and Ghoneim (1986).

\section{Statistical analysis:}

Data were analyzed by means of correlation coefficients, using COSTAT 2.0 statistical analysis software.

\section{Results and Discussion}

The pigment contents of Chlorella vulgaris cells grown under autrotrophic and heterotrophic conditions were shown in Table 1. Chlorophyll "a" content of autotrophic cells was double that estimated in heterotrophic cells (4.481 and 2.672 $\mathrm{mg} \mathrm{g}^{-1} \mathrm{dw}$, respectively). On contrary, chlorophyll "b" content of autotrophic grown cells was nearly half the value recorded for heterotrophic cells ( 0.563 and $1.071 \mathrm{mg} \mathrm{g}^{-1} \mathrm{dw}$, respectively). The heterotrophic ratio of chl-a to chl-b lost about $68.65 \%$ of its value in autotrophic grown cells. Carotenoids content of heterotrophic cultures decreased by $30.82 \%$ compared to its value for autotrophic cultures. The results in Table $1(\mathrm{~A} \& \mathrm{~B})$ showed that the significantly enhancement effect of light on chlorophyll "a" and carotenoids synthesis seemed remarkably under photoautotrophic conditions. However, under heterotrophic conditions, chlb content was significantly increased on the expense of the production of other pigments. These results suggest that when there is an organic carbon source like glucose in the culture medium and in absence of light, C. vulgaris favor the formation of chl-b. This agree with the work of Misonou and Pachlavuni (1986), who suggested that under heterotrophic conditions the synthesis pathways of chl. "a" and carotenoids are blocked or at least slow down, while the synthesis pathway of chl. "b" was greatly promoted. Another possible explanation was driven by Vladimirova (1976), who found ultra structural alterations in the photosynthetic apparatus of Chlorella sp. grown heterotrophically. It is possible that our result of the variation in pigment content under different trophic conditions, in this study, is related to such suggestion.

Egyptian J. of Phycol. Vol. 9, $2008 \quad \mathbf{- 8 8}$ - 
Table 1. Contents ( $\mathrm{mg} \mathrm{g}^{-1} \mathrm{dw}$ ) (A) and Correlation coefficients (B) of chlorophyll a, chlorophyll -b, and carotenoids of Chlorella vulgaris grown under autotrophic and heterotrophic conditions for 9 days .

(A)

\begin{tabular}{c|c|c}
\hline Pigment & Autotrophic & Heterotrophic \\
\hline Chl-a & $4.481 \pm 0.7$ & $2.672 \pm 0.3$ \\
Chl-b & $0.563 \pm 0.2$ & $1.071 \pm 0.2$ \\
Chl-a / Chl-b ratio & $7.959 \pm 0.7$ & $2.495 \pm 0.5$ \\
Carotenoids & $6.064 \pm 0.8$ & $4.195 \pm 0.4$ \\
\hline
\end{tabular}

(B)

\begin{tabular}{c|c|c}
\hline \multicolumn{2}{c|}{ Variables } & $\begin{array}{c}\text { Degree of } \\
\text { significance }\end{array}$ \\
\hline \multirow{2}{*}{ Chl-a } & Chl-b & $* *$ \\
& Chl-a / chl-b & $* * *$ \\
& Carto. & $* * *$ \\
\hline Chl-b & Chl-a / chl-b & $* *$ \\
& Carto. & $*$ \\
\hline Chl-a / chl-b & Carto. & $* * *$ \\
\hline
\end{tabular}

$0.05<*$ means significant at $\mathrm{p}$

$0.01<* *$ means significant at $\mathrm{p}$

$0.01<* * *$ means highly significant at $\mathrm{p}$

On comparing protein content of $C$. vulgaris cells grown under autotrophic and heterotrophic conditions, there was a slight decrease $(6.05 \%)$ in the protein content (Table 2 A \& B). When the composition of total free amino acids and proline of Chlorella grown autotrophically is compared to that grown heterotrophically, it was found that a significant increase in total free amino acids and proline (65.86 and $42.86 \%$, respectively) (Table $2 \mathrm{~A} \& \mathrm{~B}$ ). It seemed that heterotrophy negatively affect the protein synthesis, while positively affect and promoted synthesis of total free amino acids and proline. That is may be due to the heterotrophic cells did not need to use the available amino acids to build up protein molecules or due to degradation of protein molecules. At the same time, the increase of amino acids and proline was expected, due its known accumulation behavior in plants subjected to different environmental stresses as light availability (Hashimoto et. al., 1982; Borowitzka, 1988; Sansawa and Endo, 2004). 
Table 2. Contents (A) and Correlation coefficients (B) of protein, proline, and total free amino acids (TFAA) of Chlorella vulgaris grown under autotrophic and heterotrophic conditions for 9 days.

(A)

\begin{tabular}{c|c|c|c}
\hline $\begin{array}{c}\text { Growth } \\
\text { condition }\end{array}$ & $\begin{array}{c}\text { Protein } \\
\left(\mathbf{m g ~ g}^{-1} \mathbf{d w}\right)\end{array}$ & $\begin{array}{c}\text { Proline } \\
\left(\mathbf{m g ~ g}^{-1} \mathbf{d w}\right)\end{array}$ & $\begin{array}{c}\text { Total free amino } \\
\text { acids } \\
\left(\mathbf{m g ~ g}^{-1} \mathbf{d w}\right)\end{array}$ \\
\hline $\begin{array}{c}\text { Autotrophic } \\
\text { Heterotrophic }\end{array}$ & $388.95 \pm 21.3$ & $301.97 \pm 16.1$ & $6.438 \pm 0.9$ \\
\hline
\end{tabular}

(B)

\begin{tabular}{c|c|c}
\hline \multicolumn{2}{c|}{ Variables } & $\begin{array}{c}\text { Degree of } \\
\text { significance }\end{array}$ \\
\hline Protein & Proline & $* * *$ \\
& TFFA & $* * *$ \\
\hline Proline & TFAA & $* * *$ \\
\hline
\end{tabular}

*** means highly significant at $\mathrm{p}<0.01$

The composition of fatty acids of C. vulgaris is presented in Figures $1 \& 2$. The percentage of most fatty acids of heterotrophy cells was relatively higher than autotrophic cells (Fig. 2). Only, three fatty acids (12:0, 14:0, and 20:0) showed different trend, where they increased under autotrophic conditions rather than heterotrophic conditions. However, except for the fatty acid 16:02 which was absent under autotrophic conditions, there was no qualitative difference between autotrophic and heterotrophic cultures, (Figures $1 \& 2$ ). Such quantitative differences could be accepted as temporary physiological response to variation in trophic status (Shinichi et. al., 1983; Zhukova and Aizdaicher, 1995; Rosa et. al., 2005). The biological importance of the utilization mechanism of glucose by Chlorella is not completely understood, but whatever, the natural circumstances which make autotrophy grown Chlorella switch to heterotrophy, a supply of exogenous carbon source might be provided (White, 1974 Cho et al., 1981; Hashimoto et. al., 1982; IP and Chen, 2005). In the presence of exogenous carbon 


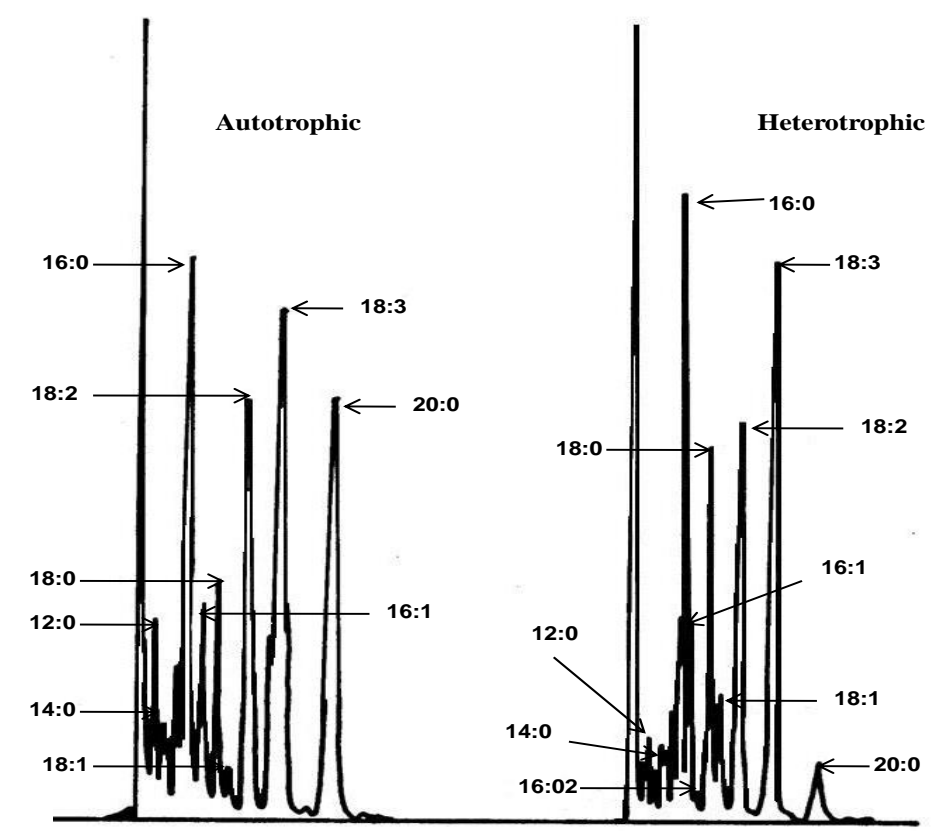

Figure 1. GLC chromatogram of fatty acids extracted from Chlorella vulgaris grown under autotrophic and heterotrophic conditions for 9 days.

like glucose, the growth and fatty acids production were enhanced (Cho et. al., 1981; Feng et. al., 2005).

However, the most important significant question is how one explains the qualitative variations in fatty acids of different species/phenotypes of the genus Chlorella? Our results showed that Chlorella vulgaris has quite a simple qualitative fatty acids composition compared to other chlorophycean species. The qualitative composition of fatty acids varied not only at species level, but also varied in different phenotypes of the same species of Chlorella (Nichols, 1965; De Mort et. al., 1972; Antonyan et. al., 1986; Vladimirova et al., 2000; Petkov and Garcia, 2007). Petkov and Garcia (2007) stated that there is no difference in 


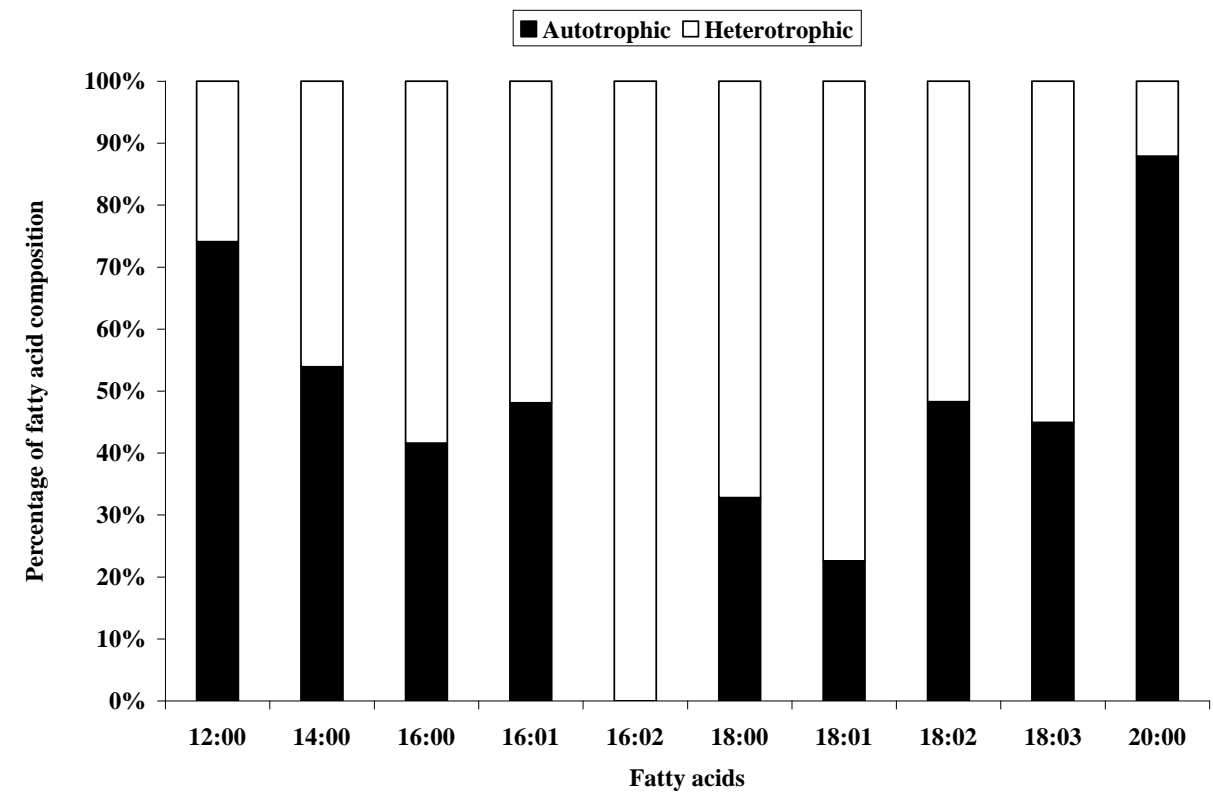

Figure 2. Difference in percentage composition of individual fatty acids extracted from Chlorella vulgaris grown under autotrophic and heterotrophic conditions for 9 days.

Table 3. Correlations coefficients for fatty acids extracted from Chlorella vulgaris grown under autotrophic and heterotrophic conditions for 9 days.

\begin{tabular}{|c|c|c|c|c|c|c|c|c|c|}
\hline \multirow[t]{2}{*}{ Fatty acids } & \multicolumn{9}{|c|}{ Variables } \\
\hline & $20: 00$ & $18: 03$ & $18: 02$ & 18:01 & 18:00 & $16: 02$ & 16:01 & $16: 00$ & $14: 00$ \\
\hline $12: 00$ & $* * *$ & $* * *$ & NG & $* * *$ & $* * *$ & $* *$ & $*$ & $* * *$ & $*$ \\
\hline $14: 00$ & $* *$ & $* *$ & NG & $* *$ & $* *$ & $* *$ & $*$ & $* *$ & \\
\hline $16: 00$ & $* * *$ & $* * *$ & NG & $* * *$ & $* * *$ & $* * *$ & $*$ & & \\
\hline $16: 01$ & $*$ & $*$ & NG & $*$ & $*$ & $*$ & & & \\
\hline $16: 02$ & $* * *$ & $* * *$ & NG & $* * *$ & $* * *$ & & & & \\
\hline $18: 00$ & $* * *$ & $* * *$ & NG & $* * *$ & & & & & \\
\hline 18:01 & $* * *$ & $* * *$ & NG & & & & & & \\
\hline 18:02 & NG & NG & & & & & & & \\
\hline 18:03 & $* * *$ & & & & & & & & \\
\hline $\begin{array}{c}\text { NG means no } \\
0.05<* \text { mean } \\
0.01<* * \text { mea } \\
0.01<* * * \text { me }\end{array}$ & $\begin{array}{l}\text { ignifica } \\
\text { significa } \\
\text { signific } \\
\text { is highly }\end{array}$ & $\begin{array}{l}\text { it } \\
\text { it at } p \\
\text { ant at } p \\
\text { signific }\end{array}$ & nt at $p$ & & & & & & \\
\hline Egyptian J. o & hycol. Vo & 9, 2008 & & $-92-$ & & & & & \\
\hline
\end{tabular}


qualitative composition of fatty acids of the genus Chlorella. Although they believed in the stability of qualitative fatty acids composition as a characteristic feature of the genus Chlorella, they drove a lot of evidences that showed a great variability in qualitative fatty acid composition in different species of Chlorella. Meanwhile, they accept the idea of using qualitative fatty acids composition as a taxonomic feature of particular species of Chlorella, they presented many explanations of the variability in qualitative fatty acids composition. For example, they revealed the presence of the fatty acids 15:0, 17:0 and 17:1 as results of culture contamination with bacteria, in agreement with others (De Mort et al., 1972; Wacker et al., 2002). Also, they explained the presence of the fatty acids 20:0, 20:1 and 20:2 on the basis of the presence of impurities with similar retention time in GLC which agreed with the results obtained by Antonyan et al., (1986) and Homova et al., (1986).

Due to the obvious variability in both qualitative and quantitative fatty acid compositions of Chlorella in this study compared to other recent reports, one should pay a lot of attention to come into acceptable conclusion for such issue. Thus, it is better to perform much detailed investigations on qualitative fatty acids composition for different Chlorella species using more sophisticated and precise techniques to come into acceptable conclusion.

Finally, considering production of natural food supplements or / and natural pharmaceutical products, it's strongly recommended using autotrophic cells of Chlorella rather than using those of heterotrophic cells for such purpose. This is because the richness in carotenoids, protein and fatty acids contents of autotrophic Chlorella.

Acknowledgement: The authors are much grateful to Dr. Mohamed Shiboob (Faculty of Agriculture, University of Alexandria) for his help in essential oil analysis.

\section{References}

Antonyan A. A.; Meleshko G. I.; Pepelyaev Y. V.; Naidina V. P. and Sukhova N. I. (1986). Comparative characterization of fatty acid of lipids from various algae. Prikl. Biokim. Mikrobiol. 22:570-576.

Astley S. B.; Hughes D. A.; Wright A. J. A.; Elliott R. M. and Southon S. (2004). DNA damage and susceptibility to oxidative damage in lymphocytes: effect of carotenoids in vitro and in vivo.Br. J. Nutr. 91:5361.

Aust O.; Stahl W.; Sies H.;Tronnier H. and Heinrich U. (2005). Supplementation with tomato-based products increases lycopene, phytofkuene, and phytoene levels in human serum and protects against UVlight-induced erythema. Int. J. Vitam. Nutr. Res. 75:54-60. 
Barclay W. R.; Meager K. M. and Abril J. R. (1994). Heterotrophic production of long chain omega-3 fatty acids utilizing algae and algae-like microorganisms. J. Appl. Phycol. 6:123-129.

Bates L. S.; Waldes R. P. and Teare I. D. (1973). Rapid determination of free proline for water stress studies. Plant Soil 39:205-207.

Bennett M. E. and Hobbie J. E. (1972). The uptake of glucose by Chlamydomonas sp. J. Phycol. 8: 389-392.

Blunt J. W.; Copp B. R.; Munro M. H. G.; Northcote P. T. and Prinsep M. R. (2005). Marine natural products. Nat. Prod. Rep. 22:15-61.

Borowitzka M. A. (1988). Vitamins and fine chemicals from microalgae, p. 153196. In Borowitzka M. A. and Borowitzka L. J. (ed.), Micro-algal biotechnology, vol. 7. Cambridge Univ. Press, Cambridge.

Brown M. R. and Miller K. A. (1992). The ascorbic acid content of eleven species of microalgae used in marine culture. J. Appl. Phycol.4:205-215.

Cantrell A.; McGarvey D. J.; Truscott T. G.; Rancan F. and Böhm F. (2003). Singlet oxygen quenching by dietary carotenoids in a model membrane environment. Arch. Biochem. Biophys.412:47-54.

Cardozo K. H. M.; Guaratini T.; Barros M. P.; Falcão V. R.; Tonon A. P.; Lopes N. P.; Campos S.; Torres M. A.; Souza A. O.; Colepicolo P. and Pinto E. (2007). Metabolites from algae with economical impact. Comp. Biochem. Physiol. 146:60-78.

Chalvardjian A. M. (1964). Fatty acids of brown and yellow fat in rats. Biochem. J. 90:518-521.

Chen F. and John M. R. (1991). Effect of C/N ratio and aeration on the fatty acid composition of heterotrophic Chlorella sorokiniana. J. Appl. Phycol. 3:203-209.

Chen F.; Zhang Y. and Guo S. Y. (1996). Growth and phycocyanin formation of Spirulina plantensis in photoheterotrophic cultures. Biotechnol. Lett. 18:603-608.

Cho B.; Sauer N.; Komor E. and Tanner W. (1981). Glucose induces two amino acid transport systems in Chlorella. Proc. Natl. Acad. Sci. 78(6):3591-3594.

Cragg G. M.; Newman D. J. and Snader K. M. (1997). Natural products in drug discovery and development. J. Nat. Prod. 60:52-60.

De Mort C. L.; Lowry R.; Tinsley I. and Phinney H. K. (1972). The biochemical analysis of some estuarine phytoplankton species. I. Fatty acid composition. J. Phycol. 8:211-216.

Dere A.; Güneş T. and Sivaci R. (1998). Spectrophotometric determination of Chlorophyll-A, B and total carotenoid contents of some algae species using different solvents. Tr. J. Bot. 22:13-17. 
Droop M. R. (1974). Heterotrophy of carbon, p. 530-559. In Stewart, W. D. P. (ed.), Algal physiology and biochemistry. Blackwell Scientific Press, Oxford.

Feng F.; Yang W.; Jiang G.; Xu T. and Kuang T. (2005). Enhancement of fatty acid production of Chlorella sp. (Chlorophyceae) by addition of glucose and sodium thiosulphate to culture medium. 40:1315-1318.

Funk C. D. (2001). Prostaglandins and leukotrienes: advances in eicosanoids biology.Sci. 294:1871-1875.

Hartree E. F. (1972). A modification of the lowery method that gives a linear photometric response. Analy. Biochem. 48:422-426.

Hashimoto S.; Setoyama Y.; Yokokura T. and Mutai M. (1982). Effects of Chlorella phospholipid on the aortic collagen and elastin metabolism and the serum lipid content in rats with experimental atheriosclerosis. Exp. Mol. Pathol. 37:150-155.

Homova T.; Gussakova S.; Glushenkova A. and Travkina I. (1986). Lipidis of Chlorella vulgaris extracts. Khim. Prir. Soedin. 3:284-288.

Ip P. F. and Chen F. (2005). Production of astaxanthin by the green microalga Chlorella zofingiensis in the dark. Process Biochem. 40:733-738.

Lichtenthaler H. K. and Wellburn A. R. (1985). Determination of total carotenoids and chlorophylls a and b of leaf in different solvents. Biol. Soc. Trans. 11:591-592.

Mayne S. T. (1996). $\beta$-Carotenoid, carotenoids and disease prevention in humans. FASEB J. 10:690-701.

Misonou T. and Pachlavuni I. K. (1986). Photosynthetic pigments of Chlorella sp. K cultured under photoauto-, mixo- and chemohetero-trophic growth conditions. Jap. J. Phycol. 34:163-170.

Molina G. E.; Belarbi E. H.; Acién F. F.G.; Robles M. A. and Chisti Y. (2003). Recovery of microalgal biomass and metabolites: process options and economics. Biotechnol. Adv. 20:491-515.

Moneam N. M. A. and Ghoneim T. (1986). Gas chromatographic analysis of total fatty acids extracted from Schinus terebenthifolius berries. J. Chromatograpgy 361:391-395.

Morimoto T.; Nagatsu A.; Murakami N.; Sakaibara J.; Tokuda H.; Nishino H. and Iwashima A. (1995). Anti-tumor promoting glyceroglycolipids from green alga, Chlorella vulgaris. Phytochem. 40:1433-1437.

Nichols B. (1965). Light-induced changes in the lipids of Chlorella vulgaris. Biochem. Biophys. Acta. 106:274-279.

Orosa M.; Torres E.; Fidalgo P. and Abalde J. (2000). Production and analysis of secondary carotenoids in green algae. J. Appl. Phycol. 12:553556.

Petkov G. and Garcia G. (2007). Which are fatty acids of the green alga Chlorella? Biochem. Syst. Ecol. 35:281-285.

Egyptian J. of Phycol. Vol. 9, 2008 
Piorreck M.; Baasch K. H. and Pohl P. (1984). Biomass production, total protein, chlorophylls, lipids and fatty acids of freshwater green and bluegreen algae under different nitrogen regimes. Phytochem. 23:207-216.

Polivka T. and Sundström V. (2004). Ultrafast dynamics of carotenoid excited states-from solution to natural and artificial systems. Chem. Rev. 104:2021-2071.

Rosa A.; Deidda D.; Serra A.; Dessi M. A. and Pompei R. (2005). Omega-3 fatty acid composition and biological activity of three microalgae species. J. Food Agric. Environ. 3:381-389.

Sánchez M. A.; Cerón G. M.C.; García C. F.; Molina G. E. and Chisti Y. (2002). Growth and biochemical characterization of micoalgal biomass produced in bubble column and airlift photobioreactors: studies in fedbatch culture. Enzy. Microb Technol.31:1015-1023.

Sansawa H. and Endo H. (2004). Production of intercellular phytochemicals in Chlorella under heterotrophic conditions. J. Biosci. Bioeng. 98(6):437-444.

Sayanova O. V. and Napier J. A. (2004). Eicosapentaenoic acid: biosynthesis routs and the potential for synthesis in transgenic plants. Phytochem. 65:147-158.

Shi X. M.; Jiang Y. and Chen F. (2002). High-yield production of leutin by the green microalga Chlorella protothecoides in heterotrophic fed-batch culture, Biochem. Prog. 18:723-727.

Shibata S.; Oda K.; Onodera-Masuoka N.; Matsubara S.; KikuchiHayakawa H.; Ishikawa F.; Iwabuchi A. and Sansawa H. (2003). Hypocholestrolemic effect of indigestible fraction of Chlorella vulgaris in cholesterol-fed rats. J. Nutr. Sci. Vitaminol. 47:373-377.

Shinichi T.; Shigehisa Y.; Kanazawa A. and Hachiro H. (1983). Effects of water temperature and salinity on eicosapentaenoic acid level of marine Chlorella. Bull. Jap. Soc. Sci. Fish. 49:805-809.

Shugarman P. M. and Appleman D. (1966). Chlorophyll synthesis in Chlorella. II. Effect of glucose and light intensity on the lag phase. Plant Physiol. 41:1701-1708.

Sies H. and Stahl W. (2004). Nutritional protection against skin damage from sunlight. Annu. Rev. Nutr. 24:173-200.

Singh S.; Kate B. N. and Banerjee U. C. (2005). Bioactive compounds from cyanobacteria and microalgae: an overview. Crit. Rev. Biotechnol. 25:7395.

Vladimirova M. G. (1976). Changes in ultrastructure of the cell of Chlorella sp. K. during its functional reorientations. Fiziologia Rastenii 23:1180-1187.

Vladimirova M. G.; Klyachko-Gurvich G. L.; Maslova I. P.; Zholdakov I. A and Bartsevich E. D. (2000). A comprehensive study of Chlorella sp. IPPAS C-48 and revision of its taxonomic position. Russ. J. Plant Physiol. 47:644-654.

Egyptian J. of Phycol. Vol. 9, $2008 \quad$ - 96 - 
Wacker A.; Becker P. and Elert E. V. (2002). Food quality effects of unsaturated fatty acids on larvae of the Zebra mussel Dreissena polymorpha. Limnol. Oceanogr. 47:1242-1248.

Wen Z. Y. (2001). A high yield and productivity strategy for eicosapentaenoic acid production by the diatom Nitzschia laevis in heterotrophic culture. $\mathrm{Ph}$. D. Dissertation. Hong Kong: The University of Hong Kong. In: Wen Z. Y.; Chen F. 2003. Heterotrophic production of eicosapentaenoic acid by microalgae. Biotechnol. Adv. 21: 273-294.

White A. W. (1974). Growth of two facultative heterotrophic marine centric diatoms. J. Phycol. 10:292-300.

Wu Z. and Shi X. (2007). Optimization for high-density cultivation of heterotrophic Chlorella based on a hybrid neural network model. Lett. Appl. Microbiol. 44:13-18.

Yem E. W. and Cocking E. C. (1955). The determination of amino-acids with ninhydrin. Analy. 80:209-213.

Zhukova N. and Aizdaicher N. (1995). Fatty acid composition of 15 species of marine microalgae. Phytochem. 39:351-356.

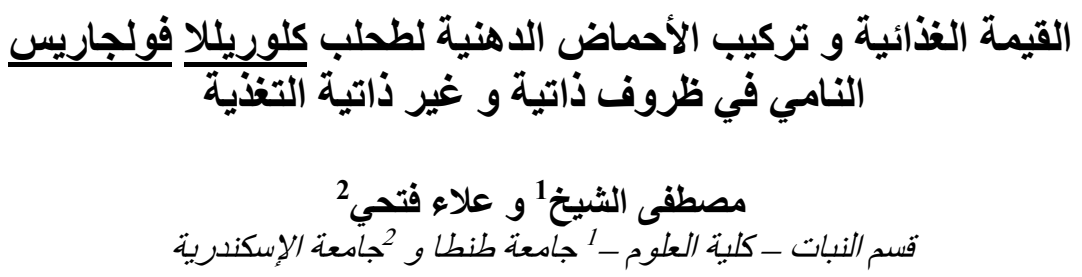

كان محتوى الكلوروفيل “،أ" في الخلايا ذاتية التغذية ضعف ما هو هو موجود في الخلايا غير

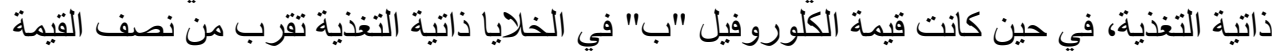

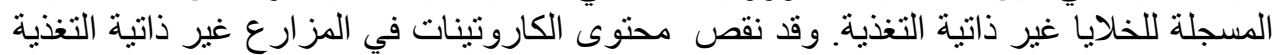

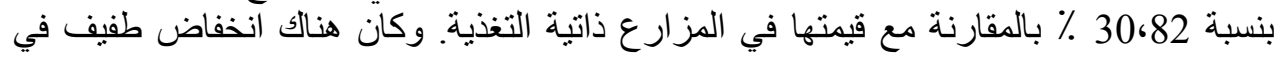

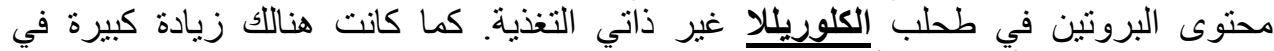

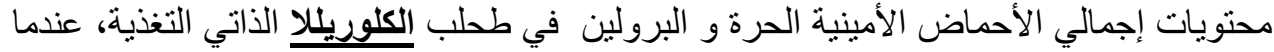

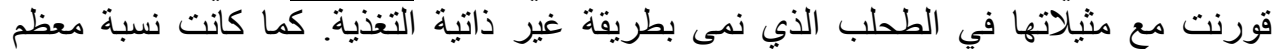
الأحماض الدهنية في الخلايا غير ذاتية التخذية اعلي نسبيا من مثنيلاتها في الخلايا ذاتية التية التغذية.

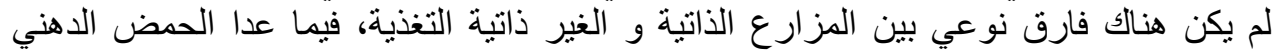
16:02 و الذي كان غائبا في ظل ظروف لين التزارع الذاتية الذاتية. 